\title{
Lipid deterioration during chilled storage of Atlantic Pomfret
}

\section{(Brama brama)}

Francisco Pérez-Alonso $^{a}$, Cristina Arias ${ }^{b}$, Santiago P. Aubourg ${ }^{a}$

${ }^{a}$ Instituto de Investigaciones Marinas (CSIC), Vigo, Spain

${ }^{\mathrm{b}}$ Departmento de Parasitología, Universidad de Vigo, Vigo, Spain

((Running Title)) Lipid deterioration in chilled pomfret

Correspondence: Santiago P. Aubourg, Instituto de Investigaciones Marinas (CSIC) c/Eduardo Cabello, 6 36208-VIGO, Spain. Phone: +34-986-231-930, Fax: +34-986292-762; e-mail: saubourg@iim.csic.es 


\section{((Abstract))}

Lipid damage produced during Atlantic pomfret (Brama brama) chilled storage (up to 19 days) was studied. The formation of various lipid parameters, such as free fatty acid and conjugated dienes $(\mathrm{CD})$, peroxide value, thiobarbituric acid reactive substances and fluorescent compounds was measured in 2 different white muscle zones (dorsal and ventral). The results were compared with the formation of volatile amines (total volatile base-nitrogen, TVB-N, trimethylamine-nitrogen, TMA-N). A gradual lipid hydrolysis was observed in both zones during the entire experiment. CD and peroxides formation was prominent during the experiment, whereas peroxides showed the highest value at day 15 in both zones followed by a peroxide breakdown at day 19. Interaction of oxidized lipids with nucleophilic compounds present in the fish muscle led to a gradual development of fluorescent material during storage in both zones. The mean value of the lipid content tended to be higher in the ventral zone than in the dorsal one, although significant differences could not be detected $(\mathrm{p}>0.05)$. Concerning the lipid damage, very small differences $(p<0.05)$ could be assessed between both zones. TVB-N content showed no variation till day 15 . At day 19 , a sharp increase was observed for both muscle zones. In the case of TMA, a gradual increase was observed in both muscles during the 19-day storage. Higher mean values of TVB-N and TMA-N indices were obtained for the ventral than for the dorsal zone. This might be due to the fact that the ventral zone is close to the viscera, where microorganisms are known to concentrate. Of all the different indices tested for quality assessment, TMA-N and the formation of fluorescent compounds were strongest related to the duration of storage $\left(r^{2} \geq 0.87\right)$. These might therefore be the most accurate parameters to follow quality loss of chilled Atlantic pomfret.

Keywords: Atlantic pomfret, chilling, muscle zones, lipid damage, amine formation. 


\section{Introduction}

Marine foods are known to provide high contents of important constituents for the human diet such as nutritional and digestive proteins, lipid-soluble vitamins (A and D, mainly), microelements (I, F, Ca, Cu, Zn, Fe and others) and polyunsaturated fatty acids (PUFA) [1-3]. However, marine species are known to easily deteriorate during processing and/or storage due to the action of different factors as microbiological development, endogenous enzyme activity, non-enzymatic lipid oxidation, and browning $[4,5]$.

During chilled storage of fish, chemical changes are known to take place $[6,7]$. Research on quality changes during chilling of lean fish species has been focused on changes in sensory attributes, formation of volatile amines and hypoxanthine, and changes in proteins and physical properties of the muscle [8-10]. However, the lipid fraction is now the subject of a great deal of attention since PUFA are highly prone to oxidation [11-12]. Previous research concerning lean fish species has shown that lipid damage may also lead to important changes during chilling concerning losses in sensory quality and nutritional value [13-15].

Atlantic pomfret (Brama brama) is a medium size pelagic fish of great economic importance [16], being widely consumed as fresh fish. Bibliography accounts for some research about its biology and fishery $[17,18]$, but little information has been provided about changes produced in this fish species due to processing [19]. The possibility of replacing higher cost species by Atlantic pomfret during the commercialization of smoked products has developed some species identification research [20, 21]. The present work is concerned with the commercialization of Atlantic pomfret as a chilled product. The study is aimed to lipid damage assessment during the ice storage and to relate it with 2 commonly employed indices (total volatile amines and trimethylamine) for assessing fish deterioration during chilling. Two different muscle zones are studied and a strong interest is accorded to the search of accurate lipid damage indices susceptible to reflect quality changes.

\section{Material and methods}

\subsection{Raw material, processing and sampling}

Fresh Atlantic pomfrets (Brama brama) were obtained in a local market. From catching till arrival to our laboratory, the fish specimens $(n=21)$ were kept in ice. The length of the fish was in the range $35.5-46.5 \mathrm{~cm}$, the weight in the range 680-1225 g. Upon arrival in our laboratory, whole individual fishes were divided into 3 batches $(n=7$ in each batch) and stored on ice in an isothermal room at $4{ }^{\circ} \mathrm{C}$. As the experiment began, all fish were in the post-rigor state. Each batch was studied separately and sampling was undertaken at days $0,2,6,9,12,15$, and 19 . Two different muscle parts were considered and sampled separately in the present study (Fig. 1): The dorsal (D) zone, placed far away from viscera and being a great proportion of the fish flesh, and the ventral $(\mathrm{V})$ zone, placed close to most viscera. Analyses were carried out on the homogenized white muscle of both zones. 


\subsection{Water and lipid contents}

The water content was determined by weight difference of the homogenized muscle (1-2 g) before and after $24 \mathrm{~h}$ at $105^{\circ} \mathrm{C}$; the results were calculated as $\mathrm{g}$ of water $100 \mathrm{~g}$ muscle.

The lipid fraction was extracted by the Bligh and Dyer [22] method. Quantification results were calculated as g lipids/100 g wet muscle.

\subsection{Lipid damage analysis}

Free fatty acid (FFA) content was determined by the Lowry and Tinsley [23] method based on complex formation with cupric acetate-pyridine. Results are expressed as g FFA/100 g lipids.

Conjugated diene (CD) formation was measured at $233 \mathrm{~nm}$ [24]. The results are expressed according to the formula: $\mathrm{CD}=\mathrm{B} \times \mathrm{V} / \mathrm{w}$, where $\mathrm{B}$ is the absorbance reading at $233 \mathrm{~nm}, \mathrm{~V}$ denotes the volume $(\mathrm{ml})$ of the sample and $\mathrm{w}$ is the mass $(\mathrm{mg})$ of the lipid extract.

Peroxide value (PV) expressed as meq oxygen/kg lipids was determined according to the ferric thiocyanate method [25].

The thiobarbituric acid index (TBA-i) (mg malondialdehyde/kg fish sample) was determined according to Vyncke [26].

Interaction compound formation was investigated by means of fluorescent properties. For it, fluorescence formation was measured with a Perkin-Elmer LS 3B (Foster City, CA, USA at $393 / 463 \mathrm{~nm}$ and $327 / 415 \mathrm{~nm}$ as described earlier [15, 27]. The relative fluorescence $(\mathrm{RF})$ was calculated as follows: $\mathrm{RF}=\mathrm{F} / \mathrm{F}_{\text {st }}$, where $\mathrm{F}$ is the fluorescence measured at each excitation/emission maximum, and $\mathrm{F}_{\mathrm{st}}$ is the fluorescence intensity of a quinine sulfate solution $\left(1 \mu \mathrm{g} / \mathrm{ml}\right.$ in $\left.0.05 \mathrm{M} \mathrm{H}_{2} \mathrm{SO}_{4}\right)$ at the corresponding wavelength. The fluorescence ratio (FR) was calculated as the ratio between both RF values: $\mathrm{FR}=\mathrm{RF}_{393 / 463 \mathrm{~nm}} / \mathrm{RF}_{327 / 415 \mathrm{~nm}}$. The $\mathrm{FR}$ value was analyzed on the aqueous phase resulting from the lipid extraction [22].

\subsection{Volatile amines formation}

Total volatile base-nitrogen (TVB-N) values were measured by the modified Antonacopoulos [28] method [27]. Fish muscle (10 g) was extracted with perchloric acid $(6 \%)$ and diluted to $50 \mathrm{ml}$. TVB-N content was obtained by steam distillation of the acid extracts brought to $\mathrm{pH} 13$ with $\mathrm{NaOH}(20 \%)$, followed by titration of the distillate with $10 \mathrm{mM} \mathrm{HCl}$. Data are expressed as mg TVB-N/100 g muscle. Trimethylamine-nitrogen (TMA-N) values were obtained by the picrate method according to Tozawa et al. [29] by employing a 5\% trichloracetic acid extract of fish muscle $(10 \mathrm{~g} / 25 \mathrm{ml})$. Data are expressed as mg TMA-N/100 g muscle. 


\subsection{Statistical analyses}

Data from the different quality measurements were subjected to the ANOVA one-way method ( $\mathrm{p}<0.05)$ and correlation analysis (linear and non-linear), comparison of means was performed using a least-squares difference (LSD) method [30].

\section{Results and discussion}

\subsection{Water and lipid contents}

The water content for each zone did not show a clear tendency (Tab. 1), although some differences $(p<0.05)$ could be observed that may be explained as a result of individual fish variation and not arising from chilling time. Comparison of both muscle zones did not provide significant $(\mathrm{p}>0.05)$ differences at any of the chilling times. An increasing water content has been reported in some small size fish species (sardine, blue whiting and horse mackerel) during chilled storage that can be explained as due to their less rigid skin than that of the Atlantic pomfret, allowing partial water entrance [15, 27, 31]. The lipid content showed some variations in both zones that could not be explained as a result of processing, but are rather arising from individual differences from fish group to fish group (Tab. 1). Mean values of the lipid content showed to be higher in the ventral zone than in the dorsal one, although comparison at any of the storage times did not provide significant differences $(p>0.05)$. Fattier fish species than Atlantic pomfret have shown a high lipid accumulation in muscle zones placed near the viscera, so that an enhancement of lipid damage in such zones during processing/storage could be observed [32, 33].

\subsection{Lipid hydrolysis}

FFA content of the initial material (dorsal and ventral muscles, Tabs. 2-3) showed higher values than in fattier fish species (mackerel, tuna) [27, 34] and lower than in leaner fish (blue whiting and hake) $[15,35]$. A slow lipolytic activity was found in both zones, a significant increase $(\mathrm{p}<0.05)$ compared to the raw material was only observed at day 19. A different hydrolysis development could not be detected $(p>0.05)$ between both zones.

\subsection{Lipid oxidation}

With the aim of assessing the lipid oxidation development, different and complementary indices were employed to obtain information about primary (conjugated diene hydroperoxides, total peroxides), secondary (thiobarbituric acid reactive substances) $[24,36]$, and tertiary (interaction compounds produced from reaction between oxidized lipids and nucleophilic compounds from the fish muscle) lipid oxidation compounds $[37,38]$.

A significant $(\mathrm{p}<0.05)$ increase in conjugated diene compounds concentration was observed in the dorsal muscle at day 12 , followed by no variations till the end of the 
experiment (Tab. 2). In the case of the ventral zone (Tab. 3), the chilling time led to a gradual increase in conjugated diene compounds concentration in the course of the whole experiment. No significant $(\mathrm{p}>0.05)$ differences were observed between both zones.

A progressive peroxide formation was observed in both zones (Tabs. 2-3) that reached a maximum mean value at day 15 , followed by a continuous breakdown of peroxides till the end of the experiment. A strong effect of chilling time was found on the peroxide formation. Significant differences $(p<0.05)$ between both zones were observed at days 2 and 15, showing a larger peroxide formation for the dorsal zone.

Detection of the thiobarbituric acid-reactive substances, showed small significant differences due to the chilling time for the dorsal zone (Tab. 2) and no differences at all for the ventral zone (Tab. 3). Comparison of both zones did not show significant differences $(\mathrm{p}>0.05)$. It can be concluded that secondary lipid oxidation was not a sensitive parameter for following the Atlantic pomfret damage during chilled storage. A continued formation of fluorescent compounds was observed in both muscle kinds during the experiment (Tabs. 2-3). Compared to the initial value, significant increases were observed at day 6 (dorsal zone) and day 2 (ventral zone). A sharp increase was observed at the end of the experiment in the dorsal zone, which agrees with the great peroxide breakdown mentioned above (Tab. 2). Comparison between both zones showed a higher $(\mathrm{p}<0.05)$ FR value at day 19 in the dorsal muscle.

\subsection{Amine formation}

Formation of total volatile compounds showed to be very slow in both kinds of muscles (Fig. 2) compared to fatty fish (mackerel and sardine) [27, 39, 40], medium fat fish (horse mackerel) [31] and lean fish (blue whiting and hake) [15, 41], where a sharp increase of volatile amine content began after 9-10 days (microorganisms lag phase) of iced storage. In the present case a significant increase $(\mathrm{p}<0.05)$ was only shown at the end of the experiment in both muscle zones (day 19). Comparison of both muscles provided a significantly higher $(\mathrm{p}<0.05)$ value at day 12 in the ventral muscle only. Determination of TMA-N index showed a progressive increase with chilling time in both zones (Fig. 3). Compared to the initial material, significant increases $(p<0.05)$ were observed at day 15 (dorsal zone) and day 9 (ventral zone). Mean values in the ventral zone were always higher than their respective dorsal ones; however, significant differences $(p<0.05)$ were only obtained in the cases of days $2,6,9$ and 15 . As in the case of the TVB-N analysis, Atlantic pomfret has shown a relatively slow formation in TMA-N compared to lean (cod) [8], medium fat (horse mackerel) [31] and fat (mackerel and sardine) $[39,40]$ fish species.

\subsection{Correlation analysis}

In order to check the suitability of the different lipid damage indices for quality changes assessment, their correlations with the storage time were studied and compared to amine formation parameters (Tab. 4).

In the case of the dorsal muscle, linear correlation provided the best results for $\mathrm{CD}$ $\left(\mathrm{r}^{2}=0.73\right), \mathrm{FR}\left(\mathrm{r}^{2}=0.80\right)$ and TMA-N $\left(\mathrm{r}^{2}=0.75\right)$ indices. By means of non-linear fittings, 
better correlation values were obtained for FR $\left(r^{2}=0.87\right)$ and TMA-N $\left(r^{2}=0.87\right)$ indices when exponential fittings were considered.

When analyzing the ventral muscle results, linear correlation provided satisfactory results again for $\mathrm{CD}\left(\mathrm{r}^{2}=0.79\right), \mathrm{FR}\left(\mathrm{r}^{2}=0.83\right)$ and TMA-N $\left(\mathrm{r}^{2}=0.86\right)$. If non-linear fittings were tested better results were obtained for $\mathrm{FR}\left(\mathrm{r}^{2}=0.88\right.$; logarithmic fitting), TVB-N $\left(\mathrm{r}^{2}=0.75\right.$; exponential fitting) and TMA-N $\left(\mathrm{r}^{2}=0.93\right.$; exponential fitting).

In all cases, exponential fitting for amine detection (TVB-N and TMA-N) offered better correlation values with the storage time than linear fitting [31]. This can be explained as a result of a fast increase in amine production after the lag phase of microorganisms $[10,27]$. In the case of peroxide production, a logarithmic trend is the most accurate, resulting from peroxide breakdown at the end of the experiment.

\section{Conclusion}

Present results have shown that chilled Atlantic pomfret developed lipid damages related to hydrolysis (FFA formation) and oxidation (CD, PV, and FR indices). Lipid oxidation detected by fluorescence formation (FR) showed an accurate tool for quality loss assessment during chilled storage and provided better correlation values than the TVB-N index.

Volatile amine formation (TVB-N and TMA-N contents) were produced in a slower pace than in other common fat and lean fish species. The presence of a rigid skin has not allowed an increase in water content in the muscle during the chilled storage and may have provided a protective effect against microorganism attack.

Little damage differences were observed between both muscle zones. As the Atlantic pomfret is not a fatty fish species, a significant difference in fat content could not be assessed $(p>0.05)$ between zones and accordingly, lipid damage, indices did not reflect a differential zone damage. However, differences in the microbiology activity were detected, showing higher $(\mathrm{p}<0.05)$ values for TVB-N and TMA-N indices in the ventral zone that could be explained by a closer location to viscera where microorganisms are known to concentrate.

\section{Acknowledgements}

The authors acknowledge Mr. Rubén Pérez-Rodríguez, Mr. Marcos Trigo and Mrs. Janet Ares for technical assistance and the Comisión Interministerial de Ciencia y Tecnología (CICyT) for financial support through the research project ALI 99-0869 (2000-2002). 


\section{References}

[1] G. Piclet: Le poisson aliment. Composition et intérêt nutritionnel. Cah. Nutr. Diét. XXII (1987) 317-335.

[2] R. Ackman, W. Ratnayake: Chemical and analytical aspects of assuring an effective supply of omega-3 fatty acids to the consumer. In: Omega-3 fatty acids in health and disease. Eds. R. Lees, M. Karel, Marcel Dekker Inc., Basel (Switzerland) 1990, pp. 215-233.

[3] A. Simopoulos: Nutritional aspects of fish. In: Seafood from producer to consumer, integrated approach to quality. Eds. J. Luten, T. Börrensen, J. Oehlenschläger, Elsevier Science, London (UK) 1997, pp. 589-607.

[4] J. Cheftel, H. Cheftel: Introducción a la bioquímica y tecnología de alimentos. Editorial Acribia, Zaragoza (Spain) 1976, pp. 237-323.

[5] R. Hsieh, J. Kinsella: Oxidation of polyunsaturated fatty acids: mechanisms, products, and inhibition with emphasis on fish. Adv. Food Res. Nutr. 33 (1989) 233-341.

[6] K. Whittle, R. Hardy, G. Hobbs: Chilled fish and fishery products. In: Chilled foods. The state of the art. Ed. T. Gormley, Elsevier Applied Science, New York (USA) 1990 pp. 87-116.

[7] G. Olafsdóttir, E. Martinsdóttir, J. Oehlenschläger, P. Dalgaard, B. Jensen, I. Undeland, I. Mackie, G. Henehan, J. Nielsen, H. Nilsen: Methods to evaluate fish freshness in research and industry. Trends Food Sci. Technol. 43 (1997) 1172-1176. 
[8] M. Chalmers, M. Careche, I. Mackie: Properties of actomyosin isolated from cod (Gadus morhua) after various periods of storage in ice. J. Sci. Food Agric. 58 (1992) 375-383.

[9] H. Rehbein, E. Martinsdottri, F. Blomsterberg, G. Valdimarsson, J. Oehlenschläger: Shelf life of iced-stored redfish, Sebastes marinus and S. mentella. Int. J. Food Sci. Technol. 29 (1994) 303-313.

[10] I. Ashie, J. Smith, B. Simpson: Spoilage and shelf-life extension of fresh fish and shellfish. Crit. Rev. Food Sci. Nutr. 36 (1996) 87-121.

[11] P. Harris, J. Tall: Rancidity in fish. In: Rancidity in foods. Eds. J. Allen, R. Hamilton, Chapman and Hall, London (UK) 1994 pp. 256-272.

[12] A. Kolakowska: Lipid oxidation in food systems. In: Chemical and functional properties of food lipids. Eds. Z. Sikorski, A. Kolakowska, CRC Press, London (UK) 2003, 133-165.

[13] G. Vidya Sagar Reddy, L. Srikar, B. Kuntia, A. Senthilvel: Lipid freshness parameters in relation to shelf life of pink perch (Nemipterus Japonicus) stored in ice. The Ind. J. Nutr. Dietet 27 (1990) 53-58.

[14] A. Khalil, E. Mansour: Control of lipid oxidation in cooked and uncooked refrigerated carp fillets antioxidant and packaging combinations. J. Agric. Food Chem. 46 (1998) 1158-1162.

[15] S. Aubourg, I. Medina, J. Gallardo: Quality assessment of blue whiting (Micromesistius poutassou) during chilled storage by monitoring lipid damages. J. Agric. Food Chem. 46 (1998) 3662-3666.

[16] FAO: Fishery statistics. Capture production. In: Food and Agriculture Organization of the United Nations. Yearbook 2000, Vol. 90/1, Rome (Italy), p. 255.

[17] H. Michaelis: Brama brama on the East Friesian coast. Drosera 78 (1978) 43-46. 
[18] A. Vázquez-Rodríguez: On the biology and fishery of ray’s bream (Brama brama). Investigación Pesquera 44 (1980) 241-252.

[19] M. Guillén, M. Errecalde: Volatile components of raw and smoked black bream (Brama raii) and rainbow trout (Oncorhyncus mykiss) studied by means of solid phase microextraction and gas chromatography/mass spectrometry. J. Sci. Food Agric. 82 (2002) 945-952.

[20] C. Sotelo, C. Piñeiro, J. Gallardo, R. Pérez-Martín: Identification of fish species in smoked products by electrophoresis and isoelectric focusing. Z. Lebensm. Unters. Forsch. 195 (1992) 224-227.

[21] A. Carrera, T. García, A. Céspedes, I. González, B. Sanz, P. Hernández, R. Martín: Immunostick colorimetric ELISA assay for the identification of smoked salmon, trout and bream. J. Sci. Food Agric. 74 (1997) 547-550.

[22] E. Bligh, W. Dyer: A rapid method of total extraction and purification. Can. J. Biochem. Physiol. 37 (1959) 911-917.

[23] R. Lowry, I. Tinsley: Rapid colorimetric determination of free fatty acids. JAOCS 53 (1976) 470-472.

[24] R. Kim, F. Labella: Comparison of analytical methods for monitoring autoxidation profiles of authentic lipids. J. Lipid Res. 28 (1987) 1110-1117.

[25] R. Chapman, J. McKay: The estimation of peroxides in fats and oils by the ferric thiocyanate method. JAOCS 26 (1949) 360-363.

[26] W. Vyncke: Direct determination of the thiobarbituric acid value in trichloracetic acid extracts of fish as a measure of oxidative rancidity. Fette Seifen Anstrichm. 72 (1970) 1084-1087.

[27] S. Aubourg, C. Sotelo, J. Gallardo: Quality assessment of sardines during storage by measurement of fluorescent compounds. J. Food Sci. 62 (1997) 295-299. 
[28] N. Antonacopoulos: Verbesserte Apparatus zur quantitativen Destillation wasserdampfflüchtiger Stoffe. Z. Lebensm. Unters. Forsch. 13 (1960) 113-160.

[29] H. Tozawa, K. Erokibara, K. Amano: Proposed modification of Dyer's method for trimethylamine determination in cod fish. In: Fish inspection and quality control. Ed. R. Kreuzer, Fishing News Books Ltd, London (UK) 1971, pp. 187-190.

[30] Statsoft: Statistica for Macintosh. Statsoft and its licensors. Tulsa, Oklahoma (USA) 1994.

[31] S. Aubourg: Damage detection in horse mackerel (Trachurus trachurus) during chilled storage. JAOCS 78 (2001) 857-862.

[32] R. Henderson, D. Tocher: The lipid composition and biochemistry of freshwater fish. Prog. Lipid Res. 26 (1987) 281-347.

[33] S. Aubourg, J. Gallardo, C. Sotelo: Distribution of triglycerides, phospholipids and polyunsaturated fatty acids in different sites in raw albacore (Thunnus alalunga) muscle: Changes after cooking. Can. Inst. Food Sci. Technol. J. 24 (1991) 287291.

[34] K. Hwang, J. Regenstein: Characteristics of mackerel mince lipid hydrolysis. J. Food Sci. 58 (1993) 79-83.

[35] A. de Koning, S. Milkovitch, T. Mol: The origin of free fatty acids formed in frozen cape hake mince (Merluccius capensis, Castelnau) during cold storage at $-18^{\circ} \mathrm{C}$. J. Sci. Food Agric. 39 (1987) 79-84.

[36] S. Melton: Methodology for following lipid oxidation in muscle foods. Food Technol. 37 (1983) 105-111, 116.

[37] J. Pokorný: Browning from lipid-protein interactions. Prog. Food Nutr. Sci. 5 (1981) 421-428.

[38] S. Aubourg: Recent advances in assessment of marine lipid oxidation by using fluorescence. JAOCS 76 (1999) 409-419. 
[39] M. Bennour, A. El Marrakchi, N. Bouchriti, A. Hamama, M. El Ouadaa: Chemical and microbiological assessments of mackerel (Scomber scombrus) stored in ice. J. Food Protect. 54 (1991) 784, 789-792.

[40] M. L. Nunes, I. Batista, R. Morao de Campos: Physical, chemical and sensory analysis of sardine (Sardina pilchardus) stored in ice. J. Sci. Food Agric. 59 (1992) 37-43.

[41] S. Baixas-Nogueras, S. Bover-Cid, M. Vidal-Carou, M. Veciana-Nogués, A. Mariné-Font: Trimethylamine and total volatile basic nitrogen determination by flow injection/gas difussion in Mediterranean hake (Merluccius merluccius). J. Agric. Food Chem. 49 (2001) 1681-1686.

[Received: March 17, 2003; accepted: June 24, 2003] 


\section{((Figure legends))}

Fig. 1. Position of the two white muscle zones considered in the present study: dorsal (D) and ventral (V) in the Atlantic pomfret (Brama brama) body.

Fig. 2. Total volatile base-nitrogen (TVB-N, mg/100 g muscle) formation in dorsal (D) and ventral (V) muscle zones of Atlantic pomfret during chilled storage.

Fig. 3. Trimethylamine-nitrogen (TMA-N, mg/100 g muscle) formation in dorsal (D) and ventral (V) muscle zones of Atlantic pomfret during chilled storage. 
Tab. 1. Water (g/100g muscle) and lipid (g/100g muscle) contents obtained in the dorsal and ventral muscle zones of Atlantic pomfret during chilled storage ${ }^{\dagger}$.

\begin{tabular}{ccccc}
$\begin{array}{c}\text { Storage time } \\
\text { [d] }\end{array}$ & \multicolumn{2}{c}{ Dorsal muscle } & \multicolumn{2}{c}{ Ventral muscle } \\
\cline { 2 - 5 } & Water content & Lipid content & Water content & Lipid content \\
\cline { 2 - 5 } 0 & $76^{\mathrm{ab}}$ & $0.62^{\mathrm{a}}$ & $77^{\mathrm{ab}}$ & $0.82^{\mathrm{ab}}$ \\
& $(0.9)$ & $(0.06)$ & $(1.3)$ & $(0.28)$ \\
2 & $77^{\mathrm{ab}}$ & $0.79^{\mathrm{ab}}$ & $77^{\mathrm{ab}}$ & $1.12^{\mathrm{ab}}$ \\
& $(1.1)$ & $(0.15)$ & $(1.0)$ & $(0.51)$ \\
6 & $77^{\mathrm{b}}$ & $0.60^{\mathrm{a}}$ & $77^{\mathrm{ab}}$ & $0.66^{\mathrm{a}}$ \\
& $(1.3)$ & $(0.03)$ & $(1.7)$ & $(0.13)$ \\
9 & $75^{\mathrm{a}}$ & $0.93^{\mathrm{ab}}$ & $75^{\mathrm{a}}$ & $0.98^{\mathrm{ab}}$ \\
& $(0.3)$ & $(0.28)$ & $(0.4)$ & $(0.21)$ \\
12 & $77^{\mathrm{b}}$ & $0.66^{\mathrm{a}}$ & $77^{\mathrm{ab}}$ & $0.93^{\mathrm{ab}}$ \\
& $(1.4)$ & $(0.12)$ & $(2.2)$ & $(0.33)$ \\
& $77^{\mathrm{a}}$ & $1.00^{\mathrm{b}}$ & $77^{\mathrm{ab}}$ & $1.38^{\mathrm{b}}$ \\
& $(0.7)$ & $(0.36)$ & $(1.3)$ & $(0.56)$ \\
15 & $79^{\mathrm{c}}$ & $0.65^{\mathrm{a}}$ & $79^{\mathrm{b}}$ & $0.71^{\mathrm{a}}$ \\
& $(0.3)$ & $(0.11)$ & $(0.6)$ & $(0.17)$ \\
ANOVA & $\mathrm{P}<0.05$ & $\mathrm{P}<0.05$ & $\mathrm{P}<0.05$ & $\mathrm{P}<0.05$ \\
\hline
\end{tabular}

${ }^{\dagger}$ Mean values $(\mathrm{n}=3)$ in the same column followed by different letters are significantly different $(p<0.05)$. Standard deviations are indicated in parentheses. 
Tab. 2. Lipid damage determination ${ }^{\dagger}$ in dorsal muscle of Atlantic pomfret during chilled storage

\begin{tabular}{cccccc}
\hline $\begin{array}{c}\text { Storage time } \\
\text { [d] }\end{array}$ & FFA & CD & PV & TBA-i & FR \\
\hline 0 & $2.60^{\mathrm{a}}$ & $0.62^{\mathrm{a}}$ & $1.83^{\mathrm{a}}$ & $0.18^{\mathrm{ab}}$ & $0.21^{\mathrm{a}}$ \\
& $(0.48)$ & $(0.10)$ & $(1.09)$ & $(0.08)$ & $(0.05)$ \\
2 & $2.52^{\mathrm{a}}$ & $0.87^{\mathrm{a}}$ & $8.71^{\mathrm{bc}}$ & $0.16^{\mathrm{a}}$ & $0.67^{\mathrm{ab}}$ \\
& $(0.74)$ & $(0.13)$ & $(0.47)$ & $(0.09)$ & $(0.06)$ \\
6 & $2.81^{\mathrm{a}}$ & $0.70^{\mathrm{a}}$ & $10.33^{\mathrm{bc}}$ & $0.18^{\mathrm{ab}}$ & $0.79^{\mathrm{bc}}$ \\
& $(1.21)$ & $(0.11)$ & $(0.70)$ & $(0.15)$ & $(0.27)$ \\
9 & $3.15^{\mathrm{a}}$ & $0.72^{\mathrm{a}}$ & $15.29^{\mathrm{cd}}$ & $0.22^{\mathrm{ab}}$ & $0.65^{\mathrm{ab}}$ \\
& $(0.22)$ & $(0.18)$ & $(0.28)$ & $(0.12)$ & $(0.17)$ \\
12 & $2.74^{\mathrm{a}}$ & $1.19^{\mathrm{b}}$ & $17.45^{\mathrm{d}}$ & $0.40^{\mathrm{b}}$ & $0.82^{\mathrm{bc}}$ \\
& $(1.17)$ & $(0.13)$ & $(3.28)$ & $(0.22)$ & $(0.06)$ \\
15 & $3.20^{\mathrm{a}}$ & $1.22^{\mathrm{b}}$ & $27.26^{\mathrm{e}}$ & $0.28^{\mathrm{ab}}$ & $1.24^{\mathrm{c}}$ \\
& $(0.84)$ & $(0.31)$ & $(3.78)$ & $(0.07)$ & $(0.28)$ \\
19 & $6.05^{\mathrm{b}}$ & $1.22^{\mathrm{b}}$ & $5.52^{\mathrm{ab}}$ & $0.18^{\mathrm{ab}}$ & $2.35^{\mathrm{d}}$ \\
& $(2.48)$ & $(0.11)$ & $(1.57)$ & $(0.09)$ & $(0.72)$ \\
ANOVA & $\mathrm{P}<0.05$ & $\mathrm{P}<0.05$ & $\mathrm{P}<0.05$ & $\mathrm{P}<0.05$ & $\mathrm{P}<0.05$ \\
\hline
\end{tabular}

${ }^{\dagger}$ Lipid damage indices: FFA (free fatty acids, g/100 g lipids), CD (conjugated dienes, calculated as expressed in the Materials and methods section), PV (peroxide value, meq. oxygen/kg lipid), TBA-i (thiobarbituric acid index, mg malondialdehyde/100 g muscle) and FR (fluorescence ratio, calculated as expressed in the Materials and methods section).

${ }^{*}$ Mean values $(\mathrm{n}=3)$ in the same column followed by different letters are significantly different $(\mathrm{p}<0.05)$. Standard deviations are indicated in parentheses. 
Tab. 3. Lipid damage determination ${ }^{\dagger}$ in ventral muscle of Atlantic pomfret during chilled storage

\begin{tabular}{cccccc}
\hline $\begin{array}{c}\text { Storage time } \\
\text { [d] }\end{array}$ & FFA & CD & PV & TBA-i & FR \\
\hline 0 & $2.84^{\mathrm{a}}$ & $0.51^{\mathrm{a}}$ & $2.39^{\mathrm{a}}$ & $0.28^{\mathrm{a}}$ & $0.20^{\mathrm{a}}$ \\
& $(0.86)$ & $(0.05)$ & $(0.41)$ & $(0.15)$ & $(0.04)$ \\
2 & $2.41^{\mathrm{a}}$ & $0.79^{\mathrm{ab}}$ & $5.71^{\mathrm{ab}}$ & $0.13^{\mathrm{a}}$ & $0.68^{\mathrm{b}}$ \\
& $(0.53)$ & $(0.07)$ & $(1.52)$ & $(0.01)$ & $(0.04)$ \\
6 & $2.56^{\mathrm{a}}$ & $0.80^{\mathrm{b}}$ & $10.12^{\mathrm{bc}}$ & $0.16^{\mathrm{a}}$ & $0.64^{\mathrm{b}}$ \\
& $(1.27)$ & $(0.21)$ & $(2.05)$ & $(0.05)$ & $(0.16)$ \\
9 & $2.42^{\mathrm{a}}$ & $0.76^{\mathrm{ab}}$ & $12.08^{\mathrm{cd}}$ & $0.27^{\mathrm{a}}$ & $0.75^{\mathrm{b}}$ \\
& $(1.06)$ & $(0.15)$ & $(5.23)$ & $(0.21)$ & $(0.05)$ \\
12 & $2.56^{\mathrm{a}}$ & $0.94^{\mathrm{bc}}$ & $11.37^{\mathrm{bc}}$ & $0.35^{\mathrm{a}}$ & $0.87^{\mathrm{bc}}$ \\
& $(1.82)$ & $(0.25)$ & $(1.89)$ & $(0.13)$ & $(0.27)$ \\
15 & $4.57^{\mathrm{ab}}$ & $1.16^{\mathrm{c}}$ & $17.98^{\mathrm{d}}$ & $0.34^{\mathrm{a}}$ & $1.18^{\mathrm{c}}$ \\
& $(2.69)$ & $(0.29)$ & $(5.51)$ & $(0.09)$ & $(0.13)$ \\
19 & $6.49^{\mathrm{b}}$ & $1.22^{\mathrm{c}}$ & $7.72^{\mathrm{abc}}$ & $0.22^{\mathrm{a}}$ & $1.07^{\mathrm{c}}$ \\
& $(3.17)$ & $(0.09)$ & $(2.96)$ & $(0.06)$ & $(0.07)$ \\
ANOVA & $\mathrm{P}<0.05$ & $\mathrm{P}<0.05$ & $\mathrm{P}<0.05$ & $\mathrm{P}<0.05$ & $\mathrm{P}<0.05$ \\
\hline
\end{tabular}

${ }^{\dagger}$ Abbreviations and units of the lipid damage indices as expressed in Tab. 2.

${ }^{*}$ Mean values $(\mathrm{n}=3)$ in the same column followed by different letters are significantly different $(p<0.05)$. Standard deviations are indicated in parentheses. 
Tab. 4. Correlation values ${ }^{\dagger}$ between the chilled storage times and chemical damage indices (lipid and amine parameters).

\begin{tabular}{ccc}
\hline Chemical index $^{\ddagger}$ & Dorsal muscle & Ventral muscle \\
\hline FFA & 0.54 & 0.53 \\
& $(\mathbf{0 . 6 3})^{\mathrm{a}}$ & $(\mathbf{0 . 6 3})^{\mathrm{a}}$ \\
CD & $\mathbf{0 . 7 3}$ & $\mathbf{0 . 7 9}$ \\
& & \\
PV & 0.51 & 0.55 \\
& $(\mathbf{0 . 6 1})^{\mathrm{b}}$ & $(\mathbf{0 . 6 4})^{\mathrm{b}}$ \\
TBA-i & 0.31 & 0.23 \\
& & \\
FR & $\mathbf{0 . 8 0}$ & $\mathbf{0 . 8 3}$ \\
& $(\mathbf{0 . 8 7})^{\mathrm{a}}$ & $(\mathbf{0 . 8 8})^{\mathrm{b}}$ \\
TVB-N & 0.49 & $\mathbf{0 . 6 1}$ \\
& $(\mathbf{0 . 6 9})^{\mathrm{a}}$ & $\mathbf{( \mathbf { 0 . 7 5 } ) ^ { \mathrm { a } }}$ \\
TMA-N & $\mathbf{0 . 7 5}$ & $\mathbf{0 . 8 6}$ \\
& $(\mathbf{0 . 8 7})^{\mathrm{a}}$ & $(\mathbf{0 . 9 3})^{\mathrm{a}}$ \\
\hline
\end{tabular}

${ }_{\dagger}^{\dagger}$ Linear correlations are expressed in all cases. Non-linear fittings (exponential ${ }^{\mathrm{a}}$ and logarithmic $\left.{ }^{b}\right)$ are expressed in brackets when the coefficients are higher than the linear ones. Significant values $(p<0.05)$ are expressed in bold print.

t Abbreviations as expressed in Tab. 2 and Figs. 2-3. 